\title{
EMPOWERMENT OF DIGITAL BASED MSMES IN COMMUNITIES IN THE NEW NORMAL ERA
}

\author{
https://ijireview.com/ijir \\ e-ISSN: \\ p-ISSN: \\ IJIR REVIEW 1 (1) (2020): 61-70
}

DOI:

Keywords: Empowerment, MSMEs,

Digital, New Normal

\section{* Corresponding Author Phone : \\ Email : dianahavinadian@gmail. com}

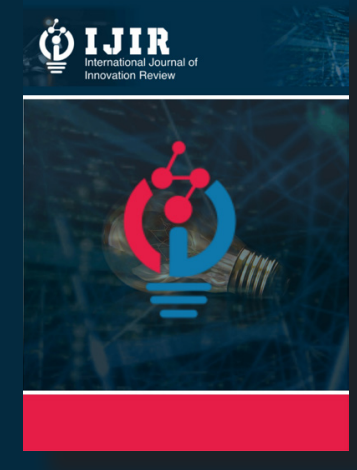

(C) Diana Nurhavina

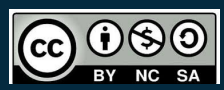

This work is licensed under the Creative Commons AttributionNonCommercial-ShareAlike 4.0 International License.

\section{Diana Nurhavina*}

Faculty of Social and Political Sciences, Airlangga University, Surabaya

Jl. Airlangga No.4 - 6, Airlangga, Gubeng, Surabaya, Jawa Timur 60115

Received: 18 August 2020; Accepted: 25 August 2020; Published online: 30 September 2020

\section{Abstract}

One of the most useful programs that can be carried out in the new normal era is to empower digital-based Micro Small and Medium Enterprises (MSMEs) to maintain the country's economic sector. Empowering digital-based MSMEs is an important effort in advancing the economic sector and surviving in the new normal era for small and mediumsized people. The method used in this research is a literature study. Where the author focuses on all literacy studies and online news which will be the main material in research and analysis explanations. There are 3 cases to be taken. Each case will be collected according to the required data criteria. Then the three will be analyzed with the support of library sources and the new normal concept and the digital economy. The results of the analysis will then be explained and presented respectively to answer the questions that have been written in the research problem formulation. So that valid data is compiled which is supported by literature sources in explaining the phenomena that occur. The research results obtained from this research itself are in the form of 3 cases regarding several companies implementing CSR community empowerment programs in the form of digital-based MSMEs. Efforts are being made and monitoring and evaluation are made to ensure that the empowerment or program can run smoothly. The several impacts obtained from the empowerment of digital-based MSMEs on the community are, 1) Improvement of the quality of society, where the provision of education by companies results in the development of good knowledge and affects their quality and performance, 2) The development of business is expanding, from provision The knowledge that has been given as well as the increased self-quality ultimately affects new thinking to achieve greater business development, 3) Increased independence which results in the emergence of a strong mentality towards business competition in any situation so that it can compete and adapt to any company both nationally or even internationally.

\section{INTRODUCTION}

Current development in Indonesia is development centered on the economy and infrastructure. The development carried out is aimed at pursuing an advanced Indonesia plan. In the process, infrastructure development has been carried out very massively and quickly so that all people can have proper infrastructure so that it can be used. Likewise, economic development has begun by pursuing the concept of Sustainable Development Goals 
(SDGs). This concept is a concept that aims to harmonize many aspects that exist within a country, including economy, social, education, law, natural environment, and culture. In this concept, the existence of sustainable development also has a big influence on the number of companies that are established in Indonesia. In Indonesia, the SDGs are realized by starting to make the Sustainable Development Goals 2030 (SDGs 2030) (Ministry of National Development Planning, 2020).

This activity is a form of global action that has been planned and agreed upon throughout the world to resolve global problems that occur and make the entire community prosperous. The development of SDGs in Indonesia has progressed quite well by successfully reducing the gap with economic growth, providing jobs and access to education, and strengthening disaster mitigation (kemlu.go.id, 2019).

As mentioned above, one of the efforts that will be made to realize the 2030 SDGs is to promote sustainable and responsible economic development. The responsibility desired is the form/action of the company that provides feedback to the community both in social and financial terms. Theresponsibilities that exist in a company can run if it is carried out with planned coordination between the company and the community, namely the stakeholders in the area. The coordination that can be carried out with the existence of the Corporate Social Responsibility (CSR) field in the company. With the two-way communication between the company through CSR and the community, it shows that a company has made efforts to support the achievement of SDGs 2030. CSR, which acts as an intermediary between the company and the community, is given full power over the communities affected by the companys activities. The existence of CSR also shows the form of responsibility carried out by a company to stakeholders and investors in utilizing the social and natural environment by considering future impacts. With the benefits generated in the surrounding environment, it shows that there is an added value for a company in its efforts to be responsible for the economic, natural, and social impacts, and to attract investors to the company it runs.

The development that is currently taking place during the Covid19 pandemic has experienced many ups and downs. This is due to the implementation of Large-Scale Social Restrictions (PSBB) to prevent the spread of the Covid19 virus which is carried out simultaneously throughout Indonesia. The implementation of the PSBB is carried out to provide opportunities and time for all medical personnel to work as much as possible. The PSBB, which aims to reduce the number of covid19 cases, hampers many activities both in the interests of the state and the common people. Health protocols that have been implemented by the government must be carried out by all people. The PSBB itself is one of the strategies made by the government by implementing regulations regarding the prohibition of leaving the house if not necessary, following health protocols when leaving the house (masks, washing hands), and temporarily stopping the activities of office workers and ordinary workers. PSBB is a limiting activity in activities carried out by the community to inhibit the spread of covid19 (Pujaningsih \& Sucitawathi, 2020). By providing strict procedures in certain areas where residents have been found contaminated by Covid19. The aim is to avoid mass losses in several sectors in Indonesia. The implementation of PSBB itself has also been regulated in the Regulation of the Minister of Health of the Republic of Indonesia Number 9 of 2020 concerning Guidelines for Large-Scale Social Restrictions in the Context of Accelerating the Handling of Corona Virus Disease 2019 (Covid-19) Chapter III Article 12 Paragraph 1 - 3 Concerning the Implementation of Large-Scale Social Restrictions.

Because there was such a ban, it ultimately resulted in the economic activity of the community is disrupted. The prohibition of leaving the house if it is not necessary and the application of social distancing has resulted in many middle to lower class people being disadvantaged because they cannot work and leave freely. Many shopping centers, offices, tourism services, and other modes of transportation have completely stopped their activities. This has a significant impact on the income that is owned by the state. Income, especially from an economic point of view, was disrupted due to the implementation of PSBB in several areas that contributed to the country's economic income. The government that feels this is very detrimental to try to think hard to run the economy again in Indonesia.

In the end, the government decided to relax through the implementation of the "New Normal" strategy. The government is slowly starting to grant permits to open shopping centers, offices, and public transportation. This policy was carried out to resume the wheels of the economy which had been hampered for several months due to the implementation of the PSBB. New Normal itself is another form of strategy from the government in carrying out state functions while still fully implementing health protocols. New Normal according to Bainus and Rachman (2020) is a result of coexistence that affects humans due to the covid19 virus so that a new rule of normality appears in society. Meanwhile, the definition of New Normal according to Suyanto et al. (2020) is a new condition that occurs after the Covid-19 pandemic which affects the lifestyle and all the needs of the community. The new normal condition affects many sectors in Indonesia and ultimately makes it possible to change the habits that occur in society. 
In this new normal era, people have been given a little leeway to be able to leave the house and work again. Some areas in Indonesia have even started their activities again, although they still have to implement health and social distancing protocols. The country's economy has also started running again with the start of the activities of several companies. Although some aspects of the field have not been able to run fully, such for example construction (construction), this is not a big problem. Because basically, the biggest and most noticeable disturbance comes from the economic sector. The failure of the country's economy resulted in drastically decreasing income and the country experiencing losses of up to. Because all activities have stopped completely suddenly, many companies cannot operate due to a lack of income. This again has a bad effect on society, namely the reduction of employees or layoffs due to salary fulfillment that cannot run normally. As a result of layoffs, people ended up unemployed and unemployed because not all people had special skills related to alternative businesses that could be done from home. The existence of hampered development has become another problem after the economy due to the implementation of PSBB. Even though infrastructure development is hampered, there is still a development that can take place during the COVID19 pandemic. Namely the development of quality human resources through community empowerment.

Community empowerment itself is an effort made by both the government and companies or certain people to improve the quality of life of the community to achieve sustainable development. Community empowerment during a pandemic can be done in many ways, especially from the corporate side. Through the CSR program, community empowerment is carried out to improve the quality of life of the community to achieve social welfare. One form of community empowerment programs that can be done is through empowering Go Digital MSMEs in the community. Even though Indonesia is currently in a transition period and some of them have entered the new normal era, this CSR program can still run smoothly. The company implements a CSR program that can be implemented and even provides many benefits to the community and even the government. By providing technologybased and business-based education, it will grow the desire to move and run the country's economy again. Besides the producers can come from all over the community, the empowerment of MSMEs can also be a contributor to state revenue.

Community empowerment is one of the main goals of CSR programs in running companies. CSR, through appropriate procedures, is obliged to prosper the community by transferring the knowledge they have so that they can be used in the current emergency. With the start of the application of the new normal era, the knowledge gained not only adds to knowledge but also increases their ability to understand current technology. With the health protocol and PSBB still being implemented in several areas, all activities are now focused on the use of technology. The use of online media has increased dramatically due to the prohibition on leaving the house. This is a great opportunity for people to be able to do business from home. CSR programs in terms of community empowerment are good investment targets and can function during the current pandemic. By empowering small MSMEs to remain productive, namely by taking advantage of the digital world to run a business that was originally offline can be turned online.

From the background described above, it can be concluded that in the end, the researcher chose to find out, analyze, and explain how the process of implementing one of the CSR programs in the field of community empowerment can remain productive in the new normal era. Researchers want to know what digital-based community empowerment carried out by CSR will provide what kind of output. This research will focus on case analysis on the implementation of community empowerment programs, namely MSMEs based on the digital era, and aims to determine some of the impacts caused by implementing CSR programs to support sustainable development and the running of the economy in Indonesia.

\section{METHOD}

The method used in this research is a descriptive qualitative method with a literature study approach. The descriptive qualitative method itself is one of the methods used to find out the facts, properties, and relationships between phenomena through detailed explanations that are carried out systematically and accurately of looking at a phenomenon (Qomariyah, 2016). This research uses a literature study because the researcher's ability to make observations and direct interviews are still limited. Qualitative research that will be carried out will look at holistically how social phenomena occur to get answers to conclusions from research questions. While research with a literature study according to Prasetyo (2010) is an activity to write the results of conclusions from various reading sources or relevant documents to provide a comprehensive explanation to be connected between previous and current findings. The data collection technique used itself is through literacy sources that come from online media, such as national and international journals, theses, theses, dissertations, books, ebooks, online news, and other literature. All sources of literacy will be 
sorted for use and as a reference for the researcher's analysis. Several online news sources in the form of the latest cases will also be included in this article to provide a more detailed and factual explanation as well as following current phenomena. So that the cases that have been collected will be taken as many as 3 cases to be concluded and used as data evidence to support data analysis later. The data analysis technique used in this study will focus on deepening the data from the available literature sources. These sources will be sorted again to be selected as important data sources and following the objectives of the research to be carried out. After the data is sorted, a valid data source is compiled which will be analyzed using the literature review that has been described. The results of the analysis will finally be explained in detail and depth to answer the two existing research problems.

\section{RESULTS AND DISCUSSION}

The concept of The New Normal according to Suyanto et al. (2020) is an impact that occurs due to the Covid19 virus which leads people to a new situation and culture. Suyanto divides the impact of the new normal era into 5 parts, namely, culture, tourism, religion, politics, and economy. The five impacts are some of the changes that occur during a pandemic that affects the human environment.

Culture becomes a form of the characteristics and identity of a nation. Culture lives on and comes from human behavior and thoughts. In this pandemic, the life of the whole community is different from usual. Implementing and implementing all health protocols is one of the important keys in helping medical personnel fight the Covid 19 virus. The form is by washing hands frequently after going out of the house, using a hand sanitizer, not touching the face before washing hands, and using a mask. This health protocol is made and mandatory for all communities. The whole community does this with frequent intensity because they have to maintain cleanliness so as not to catch the virus. This intensity occurs and is increasing along with people's awareness of their cleanliness.

Those who initially still underestimated washing their hands became more frequent when they wanted to handle food or just started doing activities outside the home. This behavior with frequent intensity has become a habit over time, resulting in a culture of washing hands. Especially in this new normal era, people who have now been given leeway to do activities at home are now becoming aware. They are already aware of the importance of maintaining health due to habits formed to adhere to health protocols. The culture of washing hands has become a habit that cannot be separated even though it has now entered a new normal period. When in contact with someone or when using public facilities, people become accustomed to inserting hand sanitizers as a complement to the trip. This is what causes the formation of new habits that occur and gives rise to a culture of handwashing in the entire community. This also applies to the use of masks, where people who are aware of the dangers of the transmission of the virus become accustomed to using masks to protect themselves.

Tourism is a fairly large source of state income in Indonesia. During the new normal period, this activity was no longer one of the main sectors that contributed to state revenue. This is due to the implementation of the PSBB regulations in all regions in Indonesia which require restrictions on public activities and gathering activities. Likewise, the tourism sector finally had to temporarily close all their activities to prevent the spread of the Covid19 virus. Tourism destinations that are closed in the end inevitably force people to return to stay at home because there are no recreational places to go to. Apart from the absence of a place to go to, people who now have awareness of the transmission of this very dangerous virus, have become reconsidering whether the destination to be destination will be free of viruses or not. Because even though the intended tourist spot is natural tourism which is still not a tourism sector and can be accessed freely, there may be no virus in that area at all.

In the field of religion, it is also one of the most difficult sectors to adapt to during the pandemic. The existence of regulations to impose restrictions on religious activities and the prohibition of gathering makes people feel that these policies are not appropriate. This also applies to the new normal era, of course. The obligation to carry out physical distancing requires all people to carry out worship activities in their respective homes. Even though there were still some people who were reckless and felt that they did not fit into the rules, the government finally dealt with it by applying patrols. This is done to discipline the public to be aware of the dangers of virus transmission and to reduce the number of patients from the virus itself. This prevailing rule also has an impact on several religious celebrations, which ultimately obliges them to stay and worship at home and not first have social gatherings with all distant relatives. This aims to avoid gathering and implementing physical distancing so that the whole family does not contract the Covid 19 virus.

Politics is also one of the sectors affected during the new normal period. Political activities and celebrations could not be carried out. Even though in the new normal era, it has been given leniency by still wearing masks, the government also still requires it to better avoid or hold associations first. For example, the implementation of regional elections and elections which ultimately hampers activities due to all prospective members being 
unable to campaign directly. So that in the end it resulted in the emergence of alternatives through virtual conversations when they wanted to have important meetings between one political elite and another.

The economic sector is one of the sectors that have the most impact after the implementation of the new normal. The existence of a vacation policy and restriction of activities in all economic activities have caused this sector to collapse or waver. The main source of state income was reduced and there was a significant loss at the time the PSBB was implemented. This condition has resulted in all companies that are not the source of human's primary needs to be willing to stop operating. As a result of all activities immediately stopped, some companies that could move without relying on direct operations ended up racking their brains and looking for other alternatives to maintain the company. The alternative is to change all activities that are usually carried out directly into digitalbased activities. All activities of employees and leaders are carried out through online media to continue company activities.

For example, in the activity of shopping for clothing, which initially people could directly visit the store, now they can no longer. This finally made the leaders compete, from having no digital platform at all to now using the digital platform as a source of support for their company's activities. All business and economic activities have been digitally based so that all their customers continue to make transactions without having to come directly to the location. Where all employees, leaders, and clients will rely on virtual communication to stay in touch with one another. So that with the implementation of the new normal, this online-based activity may continue. Apart from being a regular activity, online meetings also provide effectiveness in reaching all people who are even hard to reach.

From all the explanations above, in essence, the new normal era has a huge impact on people's lifestyles. All offline-based activities have now completely changed to online-based. This lifestyle is carried out continuously and ultimately results in a new normal activity in society. These norms and changes will continue to go hand in hand with the old habits of the abandoned society. All activities carried out in the new normal era force people to face their social and virtual lives. This, of course, has had many different impacts on several generations. Especially the older generation who have to adapt to the digital world. So that this will also be an adaptation of the digital economy that forms a new normal that occurs in all societies.

According to the digital economy Ciocoiu (2011), the is a change in the business economy that occurs with technological advances that have implications for capital, knowledge, and networks during the post-industrial economic transition period. He also argues that this technology has now become one of the high opportunities for humans to face all problems in achieving sustainable development even though sometimes it is still not 'friendly' to the natural environment. In short, Guo et al (2017) stated that the digital economy is an economy based on digital information that is used to support company development and the promotion of company products to facilitate information exchange. The digital economy is also used to provide a global business platform that serves as a source of support for communication and cooperation between business people (Guo et al., 2017).

Meanwhile, according to Terranova (2000), the digital economy is a form of 'catch' with values and free work culture. According to him, the digital economy focuses more on working on production through indirect and specific services such as web design, digital services, and multimedia production that joins newspaper chat, as well as people's life stories. Terranova also revealed that the digital economy model emerged together with the expansion of the cultural industry, thus forming an economic experiment due to external influences (beyond knowledge). The digital economy is important because of economic innovation that facilitates the economic production process. This is driven by the strength of the economic, political, and international sectors, which eventually become the basis of business innovation technological(Bukht \& Heeks, 2017). In his research, the definition of the digital economy is explained as an external result of economic activity that functions to carry out business models and digital services sourced from technological systems.

In research in Indonesia itself, many also argue about the digital economy, a phenomenon that occurs in the economic world due to the buying and selling process through electronic media (Santoso et al., 2017). This affects the operation of the economic system which is beginning to enter the transition from an in-person process to an online process. These activities are not limited to the company's business activities, but the entire economic sector at various levels/classes. Starting from the work process to the meeting, everything will intersect with technology or the internet for all business employees.

In line with this, Sahab et al., (2018) also revealed that the process of digitization in the world of the economy ultimately has an impact on job stability and a push for innovation due to increased technological knowledge. This can be done with the government's contribution to policies in the economic sector. One of them is the implementation 
of the Creative Economy, MSMEs Economy, and Digital Economy optimally in all regions in Indonesia as a form of implementing programs for strengthening the Indonesian economy (Pudhail \& Baihaqi, 2017). Internet penetration is considered to be one of the keys to measuring a country's potential when implementing the digital economy (Pudhail \& Baihaqi, 2017). However, even with government support, the digital economy may also have drawbacks, for example in transaction systems, cybersecurity, consumer protection, integrity, and most importantly the security of transactions in the form of digital finance (Setiawati, 2018).

However, the existence of a digital economic system also has an impact on the course of social interaction in society. The interactions made by business people will move from offline to online activities. This is what ultimately triggers social interaction technology (Redondo, 2015). This interaction includes all social and business activities that occur in technology networks or utilize technology as a means of life support. Redondo also stated that this interaction has a transformational effect as evidence of social collaboration with interactive computing through various digital social interaction tools. For example, online discussion forums, blogs \& wikis, online social networks, virtual worlds, folksonomies, podcasts \& webcasts, photo \& video sharing, and geotagging. These tools are one of the online media that are often used by business people in conducting research or meetings and carrying out their production activities.

According to Jabłoński (2018), the digital economy is currently very popular and is focused on by many modern companies. Where in its implementation, according to Jablonski, the digital economy will achieve long-term goals within the company. These digital economic technologies include: 1) the use of factory automation (advanced robotics), 2) the Internet of Things as a data source and internet connectivity in various areas Internet of things, 3) cloud computing, 4) big data analytics, and (5) artificial intelligence (AI). The use of the digital economy in companies is a form of realization of increasingly sophisticated technology. Where these uses often focus a lot on several activities that are social, for example, aimed at empowering society in today's modern era. Even so, of course, there are still many shortcomings that can be obtained from the use of technology to achieve the goals of the digital economy by companies. So it also requires the efforts of all elements to make this a success. So that the development of the digital economy can be carried out massively and smoothly. For example, in community empowerment efforts through CSR programs in the form of digital MSMEs. Where these activities focus on developing technology or utilizing technology for MSMEs players affected by the Covid-19 pandemic to be able to continue their activities and run their business even in new normal application conditions.

\section{A. BNI CSR Activities}

One example of a company implementing this program is BNI, which currently has a program to support MSMEs Go Online (BNI, 2020). This company, to support economic development in the new normal era, is implementing a solution in the form of advancing the digital fostered MSMEs sector. The decline in the level of buying and selling has had an impact on all small and medium enterprise producers. To revive this business, BNI established a CSR program to improve business with the goal of "Go Modern, Go Digital, and Go Online". This effort was made to continue to help MSMEs live and do business even though in the current new normal era. This is manifested in the presence of promotional assistance carried out to support the sales of all products owned by BNI-assisted MSMEs. The assistance is in the form of an e-catalog or an electronic version of the catalog where all the products of the assisted MSMEs will be marketed into the catalog/magazine.

In the current new normal era, many people avoid traveling outside of the house so they choose to make buying and selling transactions from inside the house. This is done through the technology they have in the form of mobile phones. Smartphones are the center of human activities in fulfilling the needs of life, so transactions also take place in this technology. With the transfer of the transaction place, ultimately demanding that all producers who initially focused on offline transactions must inevitably switch to online transactions. So that even though the activities of producers are halted due to PSBB, they will not be a big problem because all producers, especially MSMEs, have entered the world of the digital economy. The business/trade center they run has been centered on an onlinebased system. BNI, which provides the e-Catalog feature, provides benefits for all MSMEs producers who are currently having business constraints due to the enactment of the PSBB. So that this feature can support the businesses of all assisted MSMEs to continue running smoothly through online-based product promotions. This of course also makes it easier for consumers to shop for the products they want without having to come directly to the location.

The running of MSMEs also shows that the national economic sector is still running. By providing easy access for all consumers and producers, this will not be a difficult matter anymore. All economic activities have been centered and supported by a digital system. Through cellphones, buying and selling transactions become easy, so that even the wheels of the economy that had been 
stopped can start again. The assistance that is also provided to advance the digital economy of BNIassisted MSMEs is the support of providing EDC machines. This machine is used to facilitate buying and selling transactions with consumers. That way, even though the implementation of the new normal is in progress, this will no longer stop the wheels of the economy. MSMEs that have focused on the digital economy supported by corporate CSR programs are certainly very beneficial for many parties. In addition to preventing the state from economic loss, this also prevents people whose production activities stop when the PSBB is enforced. So that the change of economic concentration towards digital towards the small economic sector will not break the wheels of the country's economy even though large economic companies have to stop as a result of the COVID-19 pandemic.

\section{B. Zilingo's CSR Activities}

Besides, another company that also implements CSR programs to implement the digital economy is Zilingo, which currently provides Zilingo Trade services which help MSMEs players face economic competition in the new normal era (Setyaningrum, 2020). In this program, it does not only focus on online access assistance for MSMEs but also on many other online activities that can support online transaction activities by MSMEs. Zilingo provides not only a form of the platform but also knowledge for MSMEs entrepreneurs in carrying out digital economic activities. To face the new normal era, finally, Zilingo focused on maintaining the wheels of the economy through empowering digital MSMEs. This is done by participating in marketing the products of MSMEs players through the Zilingo trade platform.

Increasing consumer behavior ultimately has an impact on transactions that take place digitally. Many macro business actors have limited activities due to COVID-19 pandemic. Even so, this is not the reason a company does not run its CSR program, one of which is by empowering the community. Assistance in providing digital platforms to market software products and services through the Zilingo trade can support economic activity even though it is in the microscope. With activities moving into the digital economy, it shows that business actors and corporate CSR are aware of the importance of keeping up with the times. The increasing need in the new normal era also has an impact on how business actors can adapt in this situation to develop their business. With the openness to new technology, this can cause the country's economy to not stop even during the period of limiting activities in the era of the COVID-19 pandemic.

An increase in consumer behavior in conducting transactions via digital shows that the new normal concept goes hand in hand with the digital economy concept. Where the community, in the new normal era, will be accustomed to doing many transactions that are centered on digital processes. So that with the procurement of platforms provided by large companies to small and medium enterprises, this helps the economic process run even in the new normal era. The many conveniences that are produced have also resulted in consumers increasingly liking and often taking advantage of buying and selling transactions on digital platforms. Not only does it still make MSMEs players have income, but also makes business people independent through the knowledge that has been given. So that in the future they can still carry out their business through digital platforms without the need for help from others.

Besides, Zilingo also provides education in the form of strategy formulation to develop good business in the digital world in the new normal era. The program that is held will provide long-term benefits for MSMEs players. One of the strategies is through adaptation in the world of social media as part of the digital world. Like after using many platforms to revive the business then what has to be done is how to develop the business. This is obtained of course through a strategy that follows consumer desires. So that in the face of the new normal era, MSMEs players have not only become users of the digital economy world but also as players in the world of the digital economy. In addition to knowledge and strategies, MSMEs actors are also required to have a strong mentality.

With so many competitors emerging in the digital economy, this is not an easy matter. It takes hard workand a strong desire thatis owned by MSMEs entrepreneurs to develop their own business. With the Zilingo trade, MSMEs entrepreneurs are given a lot of assistance to empower MSMsE entrepreneurs to become digital MSMEs. So that even in facing the Covid19 pandemic and the new normal era, MSMEs actors can more easily adapt and even go through this period.

\section{Telkom Group CSR activities}

The last one is the Telkom group company which also has a CSR program that also focuses on community development in the context of advancing digital MSMEs. This program is called Patriot Desa Digital (telkomsel.com, 2019). This program is part of the CSR program by the Telkom Group of Companies in 2019 which aims to provide education to the public about how to take advantage of the digital world in running the economy. Community empowerment is one of the community development efforts in terms of thoughts and actions they have. Many efforts can be made, one of which is empowering the digital economy community. 
Telkom tries to channel knowledge through the company's CSR program to society to achieve a digital society. This achievement will have a big impact on the quality of themselves and the business abilities of the community, especially MSMEs. This program contains community empowerment in the form of providing education related to how people use digital in developing economic businesses in their region. Activities were carried out in the form of seminars, workshops, and assistance to business actors in certain villages that have been selected. This program begins with the distribution of education because the main objective needed in understanding the world of the digital economy is sufficient knowledge first and then supporting experience. So that it focuses on literacy and practice in the form of group discussion forums, roleplay, and many other practices to understand strategies and tips in the world of the digital economy. In addition to MSMEs, this CSR program also focuses on BUMDES or village-owned enterprises.

This guidance will provide direct experience to the community about ways that can be done in advancing their business through digital platforms. So that with the amount of knowledge and experience they have gained, this can also be sustainable because of the transmission of information from one person to another. That way, the economic empowerment of the digital society can certainly affect the development and ways of surviving MSMEs business actors in facing the current new normal era. The increasing public consumption pattern in the new normal era is the beginning of a new habit where online buying and selling transactions will be a more natural or common thing in the future. This transfer of transaction processes is of course accompanied by adaptations from business actors, both macro and micro.

As a macro company, running CSR to promote economic development is a natural thing. Even in the new normal era, companies are still responsible and empowering the community. One of them is through empowerment activities for the MSMEs sector which have been transferred to digitalbased. Where business actors operate according to consumer desires, it does not only apply to macro companies. However, it can also apply to microcompanies. If this is done with good cooperation, the wheels of the economy in Indonesia may run smoothly or even increase. So from this, it can be seen that the need to develop the MSME sector to be digitally based can increase state income and the economic level of the community.

Some of theimpactsfeltafter theimplementation of digital-based MSMEs empowerment includes:

\section{1. dvancing the quality of society}

The existence of CSR programs that try to empower people to understand the digital economy is carried out by providing education. Providing education and deepening of material, has resulted in many MSMEs players being able to take advantage of the digital world as best as possible. Their increased understanding and knowledge has shown that the CSR program to empower communities has been successful. With the success of this program, not only the community will benefit but also the government and the company itself.

\section{The development of business is expanding.}

The existence of community empowerment in digital-based MSMEs is shaping new thinking that is happening to MSMEs players. Armed with the knowledge and more or less experience gained from the company's CSR program, finally, it brings benefits to MSMEs players. Among them is an understanding of tips and strategies to use technology and even develop their business businesses.

\section{Increasing the independence of the}

The company's CSR program not only helps the business development of MSMEs players but also helps develop the character of the actors. The implementation of community empowerment also has an impact when people are faced with the same situation to maintain the running of their business. With a strong mentality, it shows that MSMEs actors will also become independent and adaptive to many urgent situations even to maintain their business. So that the new normal era or the existence of PSBB will never happen to him again.

\section{Conclusion}

The new normal era is a transitional era from the existence of the PSBB regulation to the easing regulations in several running sectors. No exception in the economic sector. Economic development efforts were interrupted due to the implementation of the PSB. Some sectors of the economy could not even operate at all which resulted in the dismissal of many employees. Likewise, the impact is felt by small and medium business actors where the implementation of PSB has an impact on the running of their business. The implementation of PSB has led to changes in fulfilling the needs of the community, all of which have started to be digitally based. Both in the needs of clothing, boards, and boards. These changes occur due to the impact of the implementation of PSBB on the community so that they feel more comfortable doing everything through digital services.

In the economic sector, many companies carry out CSR programs to empower communities where one of the efforts is to advance MSMEs to be digitalbased. Activities focused on channeling information 
held by the company's CSR to MSMEs players who have been selected to be empowered in the face of the new normal era. The empowerment that is carried out has an impact on the development of the microeconomic sector in a country. So that if community empowerment is carried out and focused on understanding business in the digital world, it is not impossible that MSMEs players can play an active role in macro or even international business and compete with many large companies. The impact brought about by community empowerment is also very beneficial where people can have a lot of knowledge so that it affects their quality, then can help expand the business they run, and even form independence that can be used in developing their own business.

\section{REFERENCES}

Bainus, A., \& Rahcman, J. B. (2020). Editorial: Pandemi Penyakit Menular (Covid-19) Hubungan Internasional. Intermestic: Journal of International Studies, 4(2), 111-123. https:// doi.org/10.24198/intermestic.v4n2.1

BNI. (2020). Bangga Buatan Indonesia di era New Normal, BNI Dorong Mitra UMKM Go Online. Bni.Co.Id. https://www.bni.co.id/id-id/ beranda/berita/siaranpers/articleid/6867

Bukht, R., \& Heeks, R. (2017). Defining, Conceptualising and Measuring the Digital Economy. In SSRN Electronic Journal (No. 68; Development Informatics). https://doi. org/10.2139/ssrn.3431732

Ciocoiu, C. N. (2011). Integrating Digital Economy And Green Economy: Opportunities For Sustainable Development. Theoretical and Empirical Researches in Urban Management, 6(1), 33-43. https://ideas.repec.org/a/rom/ terumm/v6y2011i1p33-43.html

Guo, S., Ding, W., \& Lanshina, T. (2017). Global Governance and the Role of the G20 in the Emerging Digital Economy. International Organisations Research Journal, 12(4), 169184. https://doi.org/10.17323/1996-78452017-04-169

Jabłoński, M. (2018). Value Migration to the Sustainable Business Models of Digital Economy Companies on the Capital Market. Sustainability, 10(9), 3113. https://doi. org/10.3390/su10093113

Kementerian PPN. (2020). Tentang SDGs. Bappenas. Go.Id. http://sdgs.bappenas.go.id/tentang/

kemlu.go.id. (2019). Indonesia Sampaikan Keberhasilan Pencapaian Sdgs di Markas PBB. Kemlu.Go.Id. https://kemlu.go.id/portal/ $\mathrm{id} / \mathrm{read} / 466 /$ berita/indonesia-sampaikankeberhasilan-pencapaian-sdgs-di-markas-pbb

Prasetyo, I. (2010). Teknik Analisis Data dalam Research and Development (pp.
1-11). uny.ac.id. http://staffnew.uny. ac.id/upload/132310875/pengabdian / teknik-analisis-data-dalam-research-anddevelopment.pdf

Pudhail, M., \& Baihaqi, I. (2017). Strategi Pengembangan Ekosistem Ekonomi Digital Indonesia. Vidya, 25(1), 69-85. https://vidya. wisnuwardhana.ac.id/index.php/vidya/ article/view/16

Pujaningsih, N. N., \& Sucitawathi, I. G. A. A. D. (2020). Penerapan Kebijakan Pembatasan Kegiatan Masyarakat (PKM) dalam Penanggulangan Wabah Covid-19 di Kota Denpasar. Moderat: Jurnal Ilmiah Ilmu Pemerintahan, 6(3), 458470. https://doi.org/10.25157/MODERAT. V6I3.3537

Qomariyah, S. (2016). Limpahan Pengetahuan pada Klaster Industri Animasi di Cimahi [Universitas Pasundan]. http://repository.unpas. ac.id/14562/

Redondo, T. (2015). The Digital Economy: Social Interaction Technologies - an Overview. International Journal of Interactive Multimedia and Artificial Intelligence, 3(2), 17-25. https:// doi.org/10.9781/ijimai.2015.322

Sahab, N. A., Maulidah, N. F., \& M, Z. N. R. (2018). Ekonomi Digital dan Pengentasan Kemiskinan Petani Kopi (Studi Kasus pada Kelompok Petani Kopi di Kecamatan Ampelgading, Sumbermanjing, Tirtoyudo, dan Dampit). LORONG: Media Pengkajian Sosial Budaya, 7(1), 87-100. http://urj.uin-malang.ac.id/index. php/lorong/article/view/227

Santoso, A. I., Ismail, A. I., \& Widiyanti, E. (2017). Kesiapan UMKM Industri Kreatif Kota Surakarta dalam Menghadapi Masyarakat Ekonomi Digital (Digital Economy Ecosystem). Seminar Nasional Pengabdian Kepada Masyarakat, 272-277. http://digilib. mercubuana.ac.id/manager/t!@file_artikel_ abstrak/Isi_Artikel_788760669024.pdf

Setiawati, S. (2018). Analisa Manajemen Kas Keuangan Desa Berbasis Digital Ekonomi Pada Pelaku Usaha Kecil Dan Menengah (UKM) \& Industri Kecil dan Menengah (IKM) Kabupaten Bogor. JURNAL LENTERA AKUNTANSI, 3(2), 65-70. https://plj.ac.id/ojs/index.php/jrakt/ article/view/243

Setyaningrum, P. M. (2020). Zilingo Trade, Platform Solusi Bisnis Satu Atap Siap Dukung UMKM Hadapi New Normal. Wartaekonomi. Co.Id. https://www.wartaekonomi.co.id/ read290110/zilingo-trade-platform-solusibisnis-satu-atap-siap-dukung-UMKM-hadapinew-normal

Suyanto, B., Egalita, N., \& Sugihartati, R. (2020). Facing the New Reality of Post Covid-19: A Demand for Lifestyle-Based Social Engineering. 
Journal of Talent Development and Excellence, 12(1), 2333-2342. http://www.iratde.com/ index.php/jtde/article/view/914

telkomsel.com. (2019). Patriot Desa Digital Memberdayakan Ekonomi Masyarakat dengan Teknologi. Telkomsel.Com. https://www. telkomsel.com/about-us/blogs/patriot-desadigital-memberdayakan-ekonomi-masyarakatdengan-teknologi
Terranova, T. (2000). Free Labor: Producing Culture for the Digital Economy. Social Text, 18(2), 33-58. https://doi.org/10.1215/0164247218-2_63-33 